\title{
Expression of Heterosis in Bivoltine Hybrids of Bombyx mori L. for Silk Yield Contributing Traits under Sub-tropical Conditions
}

\author{
Mokshe Sajgotra ${ }^{{ }^{*}}$ and R. K. Bali ${ }^{1}$ \\ ${ }^{1}$ Division of Sericulture, Sher-e-Kashmir University of Agricultural Sciences and Technology of Jammu, \\ Udheywalla, Jammu \& Kashmir (180 001), India
}

\section{Article History}

Manuscript No. AR1490b

Received in $13^{\text {th }}$ November, 2015

Received in revised form $29^{\text {th }}$ March, 2016

Accepted in final form $4^{\text {th }}$ April, 2016

\section{Correspondence to}

"E-mail: mokshesajgotra@gmail.com

\section{Keywords}

Heterosis, hypersericigenous, thermotolerent, adaptable, evaluation

\begin{abstract}
Synthesis of new-gene combinations by genetic manipulation is one of the powerful tools in exploiting the commercial qualities of plants and animals. The fundamental aim of silkworm breeding is to get robust and sturdy silkworm larvae for easy rearing and production of quality cocoon crop. Bivoltine breeds and hybrids excel in quality and productivity but do not display the crop stability. The main reason attributed to such instability is that the bivoltine breeds/hybrids suffer badly in adverse conditions. In the present study, an attempt was made to evaluate twenty-eight bivoltine hybrids raised by involving half $(8 \times 8)$ diallel set of bivoltine breeds including four hypersericigenous $\left(\mathrm{PO}_{1}, \mathrm{PO}_{3}, \mathrm{ND}_{2}\right.$ and $\mathrm{ND}_{5}$ ) and four thermotolerents (Udhey-1, Udhey-3, Udhey-4 and Udhey-6) along with ruling bivoltine hybrid, $\mathrm{SH}_{6} \times \mathrm{NB}_{4} \mathrm{D}_{2}$ in order to identify the thermotolerent, adaptable bi $\times$ bivoltine silkworm hybrids suited for sub-tropical climate. Observations were made on eight economically important traits namely, larval weight, crop weight, single cocoon weight, single shell weight, shell ratio, average filament length, non-breakable filament length and denier. The data was analyzed using Evaluation index (E.I.) method. Ten hybrid combinations recorded mean evaluation index (E.I.) values of $>50$ ranging from 51.13 to 63.35 , whereas, control scored E.I. value of 49.22 only. Two hybrid combinations, $\mathrm{ND}_{5} \times \mathrm{PO}_{1}(63.35)$ and $\mathrm{ND}_{2} \times$ Udhey $-6(60.12)$ recorded Average E.I. value $>60$ for all the characters under sub-tropical conditions.
\end{abstract}

\section{Introduction}

Silk-the queen of textiles is adorned by rich and poor alike. Sericulture is an important component of the diversified agriculture which plays a vital role in generating employment opportunities for the masses of the farming community including women and the farmers with small land holdings to land less in the rural areas for livelihood (Trivedi and Sarkar, 2015). It denotes not only the industry concerned with the mulberry cultivation, silkworm rearing or reeling sector but also the science providing technical basis for the industry (Nowlakhe and Nawalakhe, 2000). The trend of sericulture development in India has shown a quantum jump in mulberry silk production with an annual production of 20,000 $\mathrm{t}$ during the last three decades (Lakshmanan and Kumar, 2012) and it enjoys the comfortable second position for the production of silk in the world next only to China, in which silkworm breeding and development of bivoltine hybrids have played a vital role. India being predominantly a tropical country with marginal sub-tropical and temperate sericulture zones, mostly multi $\times$ bivoltine hybrids is reared in tropical areas of the country which do not meet the international standards. The silk produced by multivoltine breeds or multi $\times$ bivoltine hybrids is not so superior and cannot be sold in the international market. Thus, there is great need and scope for improving the bivoltine sericulture of the country (Datta et al., 2001). As a result, more emphasis needs to be given to bivoltine sericulture, if India has to produce international grade silk. Realizing the importance of bivoltine sericulture, efforts are being made by silkworm breeders (Babu et al., 2005; Guruswami, 2006 and Moorthy et al., 2007) of the country to evolve high yielding bivoltine silkworm breeds/hybrids for commercial purpose over years through conventional breeding approach and genetic improvement of multiple traits. Most of the silkworm breeding programmes now-a-days are oriented towards boosting the bivoltine silk yield and fiber quality.

The northern states of India, such as Jammu \& Kashmir, 
Himachal Pradesh, Uttrakhand and some pockets of Punjab assumes special significance due to its salubrious climate congenial for rearing of bivoltine silkworms and these states have observed an increasing trend in cocoon production and has a high potential for bivoltine sericulture activities (Shah, 1993). However, this production is limited to spring season (March/April) as only one commercial rearing is conducted throughout the year, though enough of mulberry leaf is available for second rearing (September/October). It is in recent years that an attempt for second commercial rearing during autumn season (September/October) has also been initiated, though the percentage of success in this period is imperatively less due to certain reasons such as poor leaf quality, high temperature, high relative humidity, and incidence of diseases besides lack of autumn specific productive silkworm breeds and hybrids (Ram, 2010; Arafat, 2014). These factors combinedly act as main constraints in boosting the silk production of the sub-tropical regions. To overcome this, the development of indigenous adaptable thermotolerent silkworm breeds/hybrids is imperative for introducing additional crop in autumn season for commercial exploitation in this region.

\section{Materials and Methods}

The present study was undertaken at Division of Sericulture, Sher-e-Kashmir University of Agricultural Sciences and Technology, Udheywalla, Jammu with an intention to develop, evaluate and identify new bi×bivoltine hybrids suitable for rearing during autumn season in sub-tropical conditions of northern India. For this purpose, four hypersericigenous $\left(\mathrm{PO}_{1}, \mathrm{PO}_{3}, \mathrm{ND}_{2}\right.$ and $\mathrm{ND}_{5}$ ) and four thermotolerent (Udhey-1, Udhey-3, Udhey-4 and Udhey-6) breeds (Table 1) were crossed to get F1 hybrids by employing half diallel method (Table 2) and studied along with ruling bivoltine hybrid, $\mathrm{SH}_{6} \times \mathrm{NB}_{4} \mathrm{D}_{2}$. All the $\mathrm{F} 1$ hybrids along with the control were reared in the completely randomized block design with three replications each during autumn 2014 and autumn 2015 (i.e. September to October). Standard rearing techniques as suggested by Krishnaswamy (1988) were followed. Data was recorded replication- wise for all the treatments viz., larval weight, crop weight, single cocoon weight, single shell weight, shell ratio, average filament length, non-breakable filament length and denier for both the seasons and the data was further pooled for both the seasons and was then analyzed using multiple trait index (Evaluation index) method.

The Evaluation Index method developed by Mano et al. (1993) was found to be very useful in selecting potential hybrids. Data on the economically important traits was collected, pooled and analyzed. The Evaluation Index (E.I.) was calculated as per the procedure:

$$
\text { Evaluation index }=\frac{\mathrm{A}-\mathrm{B}}{\mathrm{C}} \times 10+50
$$

Where, $\mathrm{A}=$ Value obtained for a particular trait of a particular hybrid combination.

$\mathrm{B}=$ Mean values of a particular trait of all the hybrid combinations.

$\mathrm{C}=$ Stand deviation of a particular trait of all the hybrid combinations.

$10=$ Standard Unit.

$50=$ Fixed Value.

The E.I. value fixed for the selection of hybrid is 50 or $>50$ for the traits. The hybrid, which scored above the limit, is considered to possess greater economic value.

\section{Results and Discussion}

Silkworm breed is the most influential factor in the development of sericulture. In the long history of sericulture, many silkworm races have been recognized as valuable for practical use and the same has been preserved. In the present study, an attempt was being made to identify the superior crossbreed through conventional breeding approach by assessment on multiple traits of the developed silkworm hybrids.

Silkworms are voracious eaters of mulberry during its larval stages and around $80 \%$ leaf is consumed in last two instars (Fukuda, 1960). Highlighting the importance of food intake,

Table 1: Salient features of parental breeds developed by Division of Sericulture, SKUAST-J

\begin{tabular}{|c|c|c|c|c|c|c|}
\hline \multirow{2}{*}{$\begin{array}{l}\text { Parent } \\
\text { breeds }\end{array}$} & \multirow{2}{*}{$\begin{array}{c}\text { Larval } \\
\text { mark- } \\
\text { ing }\end{array}$} & \multirow{2}{*}{$\begin{array}{c}\text { Cocoon } \\
\text { shape }\end{array}$} & \multirow{2}{*}{$\begin{array}{l}\text { Co- } \\
\text { coon } \\
\text { colour }\end{array}$} & \multicolumn{3}{|c|}{ Average E.I. } \\
\hline & & & & $\begin{array}{c}\text { Single } \\
\text { co- } \\
\text { coon } \\
\text { weight } \\
(\mathrm{g})\end{array}$ & $\begin{array}{l}\text { Single } \\
\text { shell } \\
\text { weight } \\
(\mathrm{g})\end{array}$ & $\begin{array}{c}\text { Shell } \\
\text { ratio } \\
(\%)\end{array}$ \\
\hline $\mathrm{U}^{*}-1$ & Marked & $\begin{array}{c}\text { Con- } \\
\text { stricted }\end{array}$ & White & 53.33 & 46.00 & 47.16 \\
\hline U-3 & Marked & $\begin{array}{c}\text { Con- } \\
\text { stricted }\end{array}$ & White & 50.00 & 42.00 & 45.63 \\
\hline U-4 & Plain & $\begin{array}{l}\text { Elon- } \\
\text { gated }\end{array}$ & White & 43.33 & 44.00 & 50.43 \\
\hline U-6 & Plain & $\begin{array}{l}\text { Elon- } \\
\text { gated }\end{array}$ & White & 45.83 & 52.00 & 27.64 \\
\hline $\mathrm{PO}_{1}$ & Plain & Oval & White & 47.50 & 50.00 & 55.10 \\
\hline $\mathrm{PO}_{3}$ & Plain & Oval & White & 52.50 & 54.00 & 55.10 \\
\hline $\mathrm{ND}_{2}$ & Marked & $\begin{array}{l}\text { Con- } \\
\text { stricted }\end{array}$ & White & 50.83 & 62.00 & 63.44 \\
\hline $\mathrm{ND}_{5}$ & Marked & $\begin{array}{c}\text { Con- } \\
\text { stricted }\end{array}$ & White & 75.83 & 74.00 & 61.09 \\
\hline
\end{tabular}




\begin{tabular}{|c|c|c|c|c|c|c|c|c|}
\hline & Udhey-1 & Udhey-3 & Udhey-4 & Udhey-6 & $\mathrm{PO}_{1}$ & $\mathrm{PO}_{3}$ & $\mathrm{ND}_{2}$ & $\mathrm{ND}_{5}$ \\
\hline Udhey-1 & $\mathrm{U}^{*}-1 \times \mathrm{U}-1$ & & & & & & & \\
\hline Udhey-3 & $\mathrm{U}-3 \times \mathrm{U}-1$ & $\mathrm{U}-3 \times \mathrm{U}-3$ & & & & & & \\
\hline Udhey-4 & $\mathrm{U}-4 \times \mathrm{U}-1$ & $\mathrm{U}-4 \times \mathrm{U}-3$ & $\mathrm{U}-4 \times \mathrm{U}-4$ & & & & & \\
\hline Udhey-6 & $\mathrm{U}-6 \times \mathrm{U}-1$ & $\mathrm{U}-6 \times \mathrm{U}-3$ & $\mathrm{U}-6 \times \mathrm{U}-4$ & U-6×U-6 & & & & \\
\hline $\mathrm{PO}_{1}$ & $\mathrm{PO}_{1} \times \mathrm{U}-1$ & $\mathrm{PO}_{1} \times \mathrm{U}-3$ & $\mathrm{PO}_{1} \times \mathrm{U}-4$ & $\mathrm{PO}_{1} \times \mathrm{U}-6$ & $\mathrm{PO}_{1} \times \mathrm{PO}_{1}$ & & & \\
\hline $\mathrm{PO}_{3}$ & $\mathrm{PO}_{3} \times \mathrm{U}-1$ & $\mathrm{PO}_{3} \times \mathrm{U}-3$ & $\mathrm{PO}_{3} \times \mathrm{U}-4$ & $\mathrm{PO}_{3} \times \mathrm{U}-6$ & $\mathrm{PO}_{3} \times \mathrm{PO}_{1}$ & $\mathrm{PO}_{3} \times \mathrm{PO}_{3}$ & & \\
\hline $\mathrm{ND}_{2}$ & $\mathrm{ND}_{2} \times \mathrm{U}-1$ & $\mathrm{ND}_{2} \times \mathrm{U}-3$ & $\mathrm{ND}_{2} \times \mathrm{U}-4$ & $\mathrm{ND}_{2} \times \mathrm{U}-6$ & $\mathrm{ND}_{2} \times \mathrm{PO}_{1}$ & $\mathrm{ND}_{2} \times \mathrm{PO}_{3}$ & $\mathrm{ND}_{2} \times \mathrm{ND}_{2}$ & \\
\hline ND5 & $\mathrm{ND}_{2} \times \mathrm{U}-1$ & $\mathrm{ND}_{2} \times \mathrm{U}-3$ & $\mathrm{ND}_{2} \times \mathrm{U}-4$ & $\mathrm{ND}_{2} \times \mathrm{U}-6$ & $\mathrm{ND}_{2} \times \mathrm{PO}_{1}$ & $\mathrm{ND}_{2} \times \mathrm{PO}_{3}$ & $\mathrm{ND}_{5} \times \mathrm{ND}_{2}$ & $\mathrm{ND}_{5} \times \mathrm{ND}_{5}$ \\
\hline
\end{tabular}

("Udhey)

Horie et al. (1978) reported that for the production of $1 \mathrm{~g}$ larval dry weight, requirement of ingestion and digestion of food is $4.2 \mathrm{mg}$ and $1.8 \mathrm{mg}$ respectively. The intake of food during total larval life was also reflected by weight of 10 mature larvae. The perusal of data (Table 3 ) revealed that three hybrids scored E.I. value $>60$ for larval weight. Similar findings were also reported by Rao et al. (1998). Minagawa and Otsuka (1975) have reported inter relationship between multiple characters in silkworm. It therefore, becomes essential to evaluate the breeds and their hybrids to understand the magnitude of heterosis towards improvement in cocoon and silk productivity (Bandopadyay, 1990). Economic characters like cocoon yield, cocoon weight, cocoon shell weight and cocoon shell percentage are inter-related and moreover they influence the productivity. In the present study, a great deal of variability was observed in the expression of crop weight. Four hybrid combinations scored E.I.>60 (Table 3) for this trait. Malik et al. (1998) suggested that cocoon yield/10,000 larvae by weight, single cocoon weight, shell weight and shell ratio percentage are important parameters for a quality cocoon crop.

The cocoon weight, shell weight and shell ratio are the important commercial parameters for cocoon stage and reeling performance. The cocoon weight has a negative correlation with shell ratio but positive correlation with shell weight whereas shell weight has a positive correlation with shell ratio. Cocoon characters are commercially important and in the present study two hybrids scored E.I. $>60$ for single cocoon weight. Saratchandra et al. (1992) has reported superior mulberry variety particularly triploids responsible for higher cocooning characters. Shell weight has a positive co-relation with cocoon shell ratio. Four hybrids scored E.I. value of $>60$; whereas, control remained at 31.90 for single shell weight character. Higher shell ratio percentage is an important character for silk filament. In hybrids, three combinations were found scoring E.I. value $>60$ for shell ratio parameter. However, control hybrid, $\mathrm{SH}_{6} \times \mathrm{NB}_{4} \mathrm{D}_{2}$ remained at E.I. value of 31.90 only (Table 3 ). Cocoon yield, pupation rate, single cocoon weight, single shell weight and shell ratio combined constitute the major qualitative and quantitative traits of the silk industry.

Among post cocoon parameters, filament length and denier are considered as important characters from economic point of view and have direct bearing on the merit of a breed or hybrid. Increase or decrease in filament length is dependent on increase or decrease in the thickness of silk filament and cocoon shell weight of breeds and hybrids (Kobari and Fujimato, 1966; Nagaraju and Kumar, 1995). Results of the present study revealed fluctuations in filament length in different hybrids. Seven and six hybrids respectively, crossed the E.I. bench mark of $>60$ for both filament length and non-breakable filament trait (Table 3). The results are in agreement with the findings of Rao et al. (2004) who observed variations in F1 hybrids. Rajalakshmi et al. (1998) opines that the quality of the good hybrid is to have minimum or no breaks during reeling. Five hybrid combinations including control crossed E.I. $>60$ for filament size. The control hybrid $\mathrm{SH}_{6} \times \mathrm{NB}_{4} \mathrm{D}_{2}$ could not qualify for total filament length andnon-breakable filament length character.

Malik et al. (2002); Ram et al. (2003) suggested that the superiority and potential of a hybrid mainly depends on the ranking and considering all the major larval, cocoonyield and silk contributing parameters. Based on these facts, ten hybrid combinations $\mathrm{ND}_{5} \times \mathrm{PO}_{1}, \mathrm{ND}_{2} \times \mathrm{U}-6, \mathrm{ND}_{5} \times \mathrm{U}-3, \mathrm{ND}_{5} \times \mathrm{U}-6$, $\mathrm{ND}_{2} \times \mathrm{PO}_{3}, \mathrm{ND}_{2} \times \mathrm{U}-1, \mathrm{ND}_{5} \times \mathrm{U}-4, \mathrm{PO}_{1} \times \mathrm{U}-6, \mathrm{ND}_{2} \times \mathrm{U}-4$ and $\mathrm{ND}_{2} \times \mathrm{PO}_{1}$ were found to be heterotic scoring E.I. value $>50$, whereas, control hybrid scored E.I. of 49.21 only. Based on this, two hybrids identified viz., $\mathrm{ND}_{5} \times \mathrm{PO}_{1}$ and $\mathrm{ND}_{2} \times$ U-6 scored E.I. value $>60$ for eight commercially important characters and may be utilized for commercial exploitation. 


\begin{tabular}{|c|c|c|c|c|c|c|c|c|c|}
\hline \multirow[t]{2}{*}{ Hybrids } & \multicolumn{9}{|c|}{ Traits } \\
\hline & $\begin{array}{l}\text { Larval } \\
\text { weight } \\
\text { (g) }\end{array}$ & $\begin{array}{l}\text { Crop } \\
\text { weight } \\
(\mathrm{kg})\end{array}$ & $\begin{array}{c}\text { Single } \\
\text { cocoon } \\
\text { weight }(\mathrm{g})\end{array}$ & $\begin{array}{c}\text { Single } \\
\text { shell } \\
\text { weight }(\mathrm{g})\end{array}$ & $\begin{array}{c}\text { Shell } \\
\text { ratio (\%) }\end{array}$ & $\begin{array}{c}\text { Average } \\
\text { filament } \\
\text { length (m) }\end{array}$ & $\begin{array}{l}\text { Non-break- } \\
\text { able filament } \\
\text { length }(\mathrm{m})\end{array}$ & $\begin{array}{l}\text { Denier } \\
\text { (d) }\end{array}$ & $\begin{array}{c}\text { Aver- } \\
\text { age E.I. }\end{array}$ \\
\hline $\begin{array}{l}\mathrm{SH}_{6} \times \mathrm{NB}_{4} \mathrm{D}_{2} \\
\text { (control) }\end{array}$ & 50.83 & 45.11 & 64.82 & 49.66 & 31.90 & 45.62 & 44.87 & 60.89 & 49.21 \\
\hline $\mathrm{ND}_{5} \times \mathrm{PO}_{1}$ & 59.26 & 64.66 & 66.92 & 68.00 & 56.26 & 67.22 & 66.17 & 58.27 & 63.35 \\
\hline $\mathrm{ND}_{2} \times \mathrm{U}-6$ & 64.46 & 57.79 & 60.00 & 62.33 & 56.37 & 66.72 & 57.07 & 56.17 & 60.11 \\
\hline $\mathrm{ND}_{5} \times \mathrm{U}-3$ & 50.05 & 56.89 & 55.08 & 58.66 & 57.00 & 62.20 & 69.88 & 64.03 & 59.22 \\
\hline $\mathrm{ND}_{5} \times \mathrm{U}-6$ & 55.40 & 57.49 & 56.92 & 61.33 & 58.75 & 64.88 & 55.48 & 61.93 & 59.02 \\
\hline $\mathrm{ND}_{2} \times \mathrm{PO} 3$ & 63.44 & 39.53 & 44.12 & 59.33 & 73.39 & 62.95 & 61.49 & 60.36 & 58.07 \\
\hline $\mathrm{ND}_{2} \times \mathrm{U}-1$ & 48.63 & 52.13 & 65.17 & 62.00 & 49.60 & 64.38 & 55.04 & 59.31 & 57.03 \\
\hline $\mathrm{ND}_{5} \times \mathrm{U}-4$ & 50.12 & 57.41 & 52.10 & 59.00 & 61.46 & 54.75 & 53.53 & 62.98 & 56.42 \\
\hline $\mathrm{PO}_{1} \times \mathrm{U}-6$ & 47.84 & 65.56 & 59.82 & 59.00 & 51.55 & 53.07 & 51.94 & 53.03 & 55.23 \\
\hline $\mathrm{ND}_{2} \times \mathrm{U}-4$ & 68.64 & 50.09 & 55.61 & 59.00 & 56.84 & 51.06 & 43.28 & 55.65 & 55.02 \\
\hline $\mathrm{ND}_{2} \times \mathrm{PO} 1$ & 54.77 & 48.06 & 56.75 & 59.00 & 55.38 & 44.78 & 45.14 & 45.18 & 51.13 \\
\hline $\mathrm{PO}_{3} \times \mathrm{U}-6$ & 27.99 & 44.28 & 39.21 & 42.00 & 50.97 & 62.62 & 70.33 & 61.93 & 49.91 \\
\hline $\mathrm{PO}_{3} \times \mathrm{U}-3$ & 55.25 & 49.56 & 55.08 & 47.66 & 39.85 & 46.37 & 53.18 & 51.98 & 49.87 \\
\hline $\mathrm{ND}_{5} \times \mathrm{ND} 2$ & 52.72 & 42.98 & 48.15 & 54.66 & 59.86 & 38.34 & 44.70 & 55.13 & 49.56 \\
\hline $\mathrm{PO}_{1} \times \mathrm{U}-4$ & 57.06 & 54.85 & 49.82 & 51.00 & 51.69 & 41.10 & 47.61 & 42.56 & 49.46 \\
\hline $\mathrm{PO}_{1} \times \mathrm{U}-1$ & 56.27 & 58.92 & 51.14 & 43.00 & 37.19 & 52.91 & 60.78 & 35.23 & 49.34 \\
\hline $\mathrm{U}-6 \times \mathrm{U}-1$ & 53.35 & 62.02 & 50.78 & 45.33 & 41.35 & 40.85 & 47.35 & 47.80 & 48.60 \\
\hline $\mathrm{ND}_{5} \times \mathrm{PO} 3$ & 57.69 & 38.17 & 43.42 & 53.33 & 64.34 & 44.53 & 32.32 & 45.18 & 47.37 \\
\hline $\mathrm{PO}_{3} \times \mathrm{PO} 1$ & 36.26 & 46.32 & 46.31 & 40.00 & 38.20 & 54.50 & 61.75 & 55.13 & 47.31 \\
\hline $\mathrm{ND}_{5} \times \mathrm{U}-1$ & 48.94 & 56.13 & 51.84 & 52.33 & 51.21 & 47.04 & 34.35 & 36.28 & 47.27 \\
\hline $\mathrm{PO}_{3} \times \mathrm{U}-1$ & 50.44 & 63.90 & 58.59 & 53.66 & 44.92 & 37.75 & 37.27 & 29.47 & 47.00 \\
\hline $\mathrm{PO}_{3} \times \mathrm{U}-4$ & 44.77 & 39.60 & 35.08 & 43.66 & 59.89 & 54.25 & 40.19 & 56.70 & 46.77 \\
\hline $\mathrm{PO}_{1} \times \mathrm{U}-3$ & 52.36 & 55.00 & 46.22 & 40.00 & 38.31 & 45.62 & 44.87 & 37.32 & 44.96 \\
\hline $\mathrm{U}-4 \times \mathrm{U}-1$ & 55.99 & 51.45 & 51.49 & 42.33 & 35.70 & 40.01 & 46.67 & 34.71 & 44.77 \\
\hline $\mathrm{ND}_{2} \times \mathrm{U}-3$ & 43.82 & 30.62 & 44.03 & 46.00 & 51.16 & 49.81 & 43.37 & 36.28 & 43.13 \\
\hline $\mathrm{U}-6 \times \mathrm{U}-3$ & 37.52 & 37.41 & 38.85 & 37.33 & 43.07 & 45.20 & 51.94 & 50.41 & 42.72 \\
\hline $\mathrm{U}-4 \times \mathrm{U}-3$ & 40.12 & 54.09 & 39.03 & 36.33 & 41.37 & 35.66 & 41.87 & 44.65 & 41.64 \\
\hline $\mathrm{U}-3 \times \mathrm{U}-1$ & 40.24 & 42.92 & 42.80 & 37.33 & 38.73 & 32.89 & 38.95 & 43.09 & 39.62 \\
\hline $\mathrm{U}-6 \times \mathrm{U}-4$ & 25.63 & 26.92 & 20.87 & 28.33 & 53.20 & 42.77 & 49.38 & 48.84 & 36.99 \\
\hline
\end{tabular}

\section{Conclusion}

Two hybrids namely $\mathrm{ND}_{5} \times \mathrm{PO}_{1}$ (Av.E.I. 63.35 ) and $\mathrm{ND}_{2} \times \mathrm{U}-6$ (Av. E.I. 60.11) can be exploited for autumn rearings in the field at farmer's level for better prospects of bivoltine sericulture in sub-tropical areas.

\section{References}

Arafat, Y., 2014. Evaluation of multi $\times$ bi silkworm (Bombyx mori L.) hybrids for autumn season.M. Sc. Thesis,
Sher-e-Kashmir University of Agricultural Sciences and Technology of Jammu, Udheywalla, Jammu, India.

Babu, R.M., Lakshmi, H., Prasad, J., Seetharamulu, J., Chandrashekharaiah, 2005. Development of new productive bivoltine silkworm (Bombyx mori L.) hybrid, APS83 $\times$ APS102. International Journal of Industrial Entomology 11(1), 27-36.

Bandopadyay, A., 1990. Utility of diallel mating designs in breeding. In: Workshop on Biometrical Genetics, Central Sericultural Research and Training Institutes, Mysore, 
India 22-27 (Abstracts).

Datta, R.K., Basavaraja, H.K., Reddy, N.M., Kumar, S.N., Kumar, N.S., Babu, R., Ahsan, M.M., Jayaswal, K.P., 2001. Breeding of new productive bivoltine hybrid, CSR12 $\times$ CSR6 of silkworm, Bombyx mori L. International Journal of Industrial Entomology 3, 127-133.

Fukuda, S., 1960. Biochemical studies on the formulation of silk protein. Part IX. Thedirect and indirect formulations of silk protein during the growth of silkworm larva. Bulletin Agricultural Chemical Society, Japan 24 (supplement), 296-401.

Guruswami, D., 2006. Breeding of promising races of silkworm Bombyx mori L. and identification of suitable hybrids for rainfed area in Karnataka. Ph.D Thesis, Bangalore University, Bangalore, India.

Horie, Y., Inokuchi, T., Watanabe, K., 1978. Quantitative studies of food utilization by the silkworm Bombyx mori L. through the life cycle II. Economy of nitrogen and amino acids. Bulletin Sericultural Experimental Station, Japan 27(2), 531-578.

Kobari, K., Fujimoto, S., 1966. Studies on the selection of cocoon filament length and cocoon filament size in Bombyx mori L. Journal of Sericultural Science of Japan $35,427-434$.

Krishnaswamy, S., 1988. Development of appropriate technology for sericulture in India. In: Proceedings of International Congress on Tropical Sericulture Practices, Bangalore, India, 55-59.

Lakshmanan, V., Kumar, N.S., 2012. Evaluation of new bivoltine silkworm hybrids of Bombyx mori L. for subtropical conditions. International Journal of Science and Nature 3(1), 129-136.

Malik, G.N., Massoodi, M.A., Kamili, A.S., Sofi, A.M., 1998. Studies on heterosis in some bivoltine silkworm (Bombyx mori L.) crosses. Journal of Sericulture 6(1 and 2), 47-49.

Malik, G.N., Kamili, A.S., Wani, S.A., Dar, H.L., Ahmed, R., Sofi, A.M., 2002. Evaluation of some bivoltine silkworm, Bombyx mori L. genotypes. SKUAST Journal of Research 4, 83-87.

Mano, Y., Kumar, N.S., Basavaraja, H.K., Reddy, N.M., Datta, R.K., 1993. A new method to select promising silkworm breeds/combinations. Indian Silk 31, 53.

Minagawa, I., Otsuka, Y., 1975. Relationships of actual performance of double cross hybrids and predicted value based on the mean value of the single crosses concerned in the silkworm Bombyx mori L. Japanese Journal of Breeding 25, 251-257.

Moorthy, S.M., Das, S.K., Kar, N.B., Urs, S.R., 2007. Breeding of bivoltine breeds of Bombyx mori L. suitable for variable climatic conditions of the tropics. International Journal of Industrial Entomology 14(2), 99-105.

Nagaraju, J., Kumar, T.P., 1995. Effects of selection on cocoon filament length in divergently by selected lines of the silkworm, Bombyx mori L. Journal of Sericultural Sciences of Japan 64(2), 103-109.

Nowlakhe, A.M., Nawalakhe, U.A., 2000. Silk: A boom to apparel industry. Employment News. XXV (13), 24-30. June, 2000.

Rajalakshmi, E., Chauhan, T.P.S., Kamble, C.K., 1998. Hybrid vigour among newly evolved bivoltine hybrids of silkworm, Bombyx mori L. under hill conditions. Indian Journal of Agricultural Science 68(9), 620-624.

Ram, K., Bali, R.K., Koul, A., 2003. Seasonal evaluation of various cross combinations in bivoltine silkworm Bombyx mori L. Journal of Research, SKUAST- J2(2), 169-177.

Ram, K., Bali, R.K., Koul, A., 2010. Identification of bivoltine breeds and their hybrids suitable for sub-tropical climate of Jammu. Geobios 33(4), 265-270.

Rao, P.R.T., Ghosh, B., Moorthy, S.M., Das, S.K., Roy, G.C., Sengupta, A.K., Sen, S.K., 1998. Combining ability, gene action and heterosis through introgressive hybridization in Bombyx mori L. Perspectives in Cytology and Genetics 9, 461-71.

Rao, P.S., Datta, R.K., Basavaraja, H.K., Kumari, K.M.V., Rekha, M., 2004. Evaluation of combining ability of certain quantitative traits through diallel crosses in the silkworm (Bombyx mori L.). Indian Journal of Sericulture 44, 75-81.

Saratchandra, B., Rajanna, L., Philomena, K.L., Paramesha, C., Ramesh, S.P., Tayappe, T., Sabitha, M.G., 1992. An evaluation of elite mulberry varieties for good yield and quality through bioassay. Sericologia 32(1), 127-134.

Shah, A.M., 1993. Cost return analysis of Sericulture in Kashmir. Indian Silk 32(5), 47-50.

Trivedi, S., Sarkar, K., 2015. Comparative study on income generation through agriculture crop and sericulture at farmer's level in Murshidabad district. Journal of Entomology and Zoology 3(1), 242-245. 